\title{
Central Bank Independence in a (Very) Non-Neoclassical World ${ }^{1}$
}

\author{
Eduardo Zambrano ${ }^{2}$
}

December, 2005

\begin{abstract}
What if it could be possible to convince a completely non-neoclassical economist of the importance of Central Bank independence? The profession currently favors arguments in favor of Central Bank independence that are based on the seminal work by Barro and Gordon (1983 a,b), a model with naturally strong neoclassical assumptions. As a consequence of this, the argument in favor of Central Bank independence routinely given by economists is often not bought by those who question the validity of the neoclassical assumptions. In this paper I argue that Central Bank independence can be beneficial for society even when the economy is entirely non-neoclassical, that is, when workers are all unionized, firms are completely cartelized and inflation arises as the result of distributive struggles among capitalists and workers. This is so because it is the time-inconsistency issue, and not the structure of the economy, that which generates the inflation bias that Central Bank independence is set to eliminate.
\end{abstract}

\footnotetext{
${ }^{1}$ I wrote this article while on sabbatical at the Central Bank of Venezuela. An earlier version of this paper circulated as part of Central Bank of Venezuela Working Paper Series \#55 (2004). I thank José Guerra, Harold Zavarce, Carolina Pagliacci, Adriana Arreaza and Alberto Unanue for stimulating conversations on this topic and everyone at the Central Bank of Venezuela for their hospitality and financial support.

${ }^{2}$ Department of Finance, Mendoza College of Business, University of Notre Dame, 238 MCOB, Notre Dame, IN 26556. Phone: 574-631-4597. Fax: 574-631-5255. E-mail: ezambran@nd.edu.
} 


\section{Introduction}

The seminal work by Barro-Gordon (1983 a,b) model is routinely used to defend the importance of Central Bank independence in modern economies. This well-known model naturally has an entirely neoclassical structure, with its assumptions of perfect competition and an expectations-augmented Phillips curve, which in turn embed the assumptions of the neutrality of money, the existence of a natural rate of unemployment and the undesirability of stabilization policies. For this, and other reasons, the argument of Central Bank independence is not bought by those who question the validity of the neoclassical assumptions.

What if it could be possible to convince a completely non-neoclassical economist of the importance of Central Bank independence? This is of obvious importance as economists worldwide are often set to give policy advice to many members of society that view modern neoclassical economics with much suspicion.

In this paper I show that one can easily argue that Central Bank independence can be beneficial for society even when the economy is entirely non-neoclassical, that is, when workers are all unionized, firms are completely cartelized and inflation arises as the result of distributive struggles among capitalists and workers. ${ }^{3}$ I show that the issues of dynamic inconsistency studied by Barro and Gordon are just as important in this 'structuralist' (e.g., very non-neoclassical) economy as in a neoclassical economy and

\footnotetext{
${ }^{3}$ In fact, this economy is not even "New Keynesian" in that the distinguishing feature of my model is not the presence of nominal rigidities in an otherwise neoclassical world (as in, for example, Clarida, Gali and Gertler, 1999, and references therein) but instead in that wages and prices are direct choices made independently by the union of workers and the cartel of firms to increase their income share.
} 
show that the inflation bias generated by dynamic inconsistency disappears in the structuralist economy once Central Bank independence is in place.

\section{The model}

As in Barro and Gordon (1983 a,b) I set myself to build the simplest possible model where the importance of Central Bank independence in an economy that does not satisfy regular neoclassical assumptions can be demonstrated. The model is extraordinarily simple and atypical. This is deliberate. The fact that this economy is very non-standard makes it all the more interesting that the Barro-Gordon $(1983 \mathrm{a}, \mathrm{b})$ results can be formulated and proved in it.

Consider an economy with one good and three agents: a group of workers, a group of capitalists, and the monetary policy authority.

This model is composed of one period that is divided in three Stages. In the first Stage workers define their inflation expectations and collectively impose their nominal wage demands onto the group of capitalists. In the second Stage the monetary policy authority define their expectations about the capitalists' future pricing decisions and takes actions that determine the level of nominal aggregate demand in the economy. In the third Stage the capitalists collectively choose prices in the economy, therefore setting the price level. I present the details below. 


\subsection{The workers}

Workers are all unionized and they collectively bargain their wage contracts with the capitalists in the first Stage. Workers are set to defend a real wage equal to $\mathrm{w}_{0}$ and have inflation expectations equal to $\pi_{0}{ }^{\mathrm{e}}$. (I assume that the initial price level $\mathrm{P}_{0}$ is equal to one). I assume that the union imposes to the group of capitalists, at Stage 1, wage contracts that guarantee a nominal wage for workers equal to

$\mathrm{W}=\mathrm{W}_{0}\left(1+\pi_{\mathrm{o}}^{\mathrm{e}}\right)$.

Equation (1) adopts an extreme point of view according to which the labor union has all the bargaining power in the wage discussions with the capitalists, as in Cukierman (1992, Ch. 3).

\subsection{The monetary policy authority}

In this model the monetary policy authority takes steps that successfully determine the level of nominal aggregate demand $\mathrm{Y}$ in the economy to strike a balance between inflation and the level of real GDP. In particular, I model the monetary policy authority as choosing at Stage 2 the level of Y to maximize

$\mathrm{Y} /\left(1+\pi_{1}\right)-(\gamma / 2) \pi_{1}^{2}, \quad \gamma>0$,

where $\pi_{1}$ is the inflation rate and $\mathrm{Y} /\left(1+\pi_{1}\right)$ is the level of real GDP. The interpretation is that the higher $\gamma$ the more averse to inflation the monetary policy authority is. At the moment of making the decision about the level of nominal aggregate demand the authority takes nominal wages as given and forms expectations about the pricing 
decisions that the capitalists will make alter they see the course of action taken by the monetary policy authority.

\subsection{The capitalists}

The capitalists are completely cartelized, and so they operate as a single monopolist. They take nominal wages as previously bargained and the level of nominal aggregate demand as given and choose at Stage 3 a price level $\mathrm{P}_{1}$ for the economy to maximize

$\mathrm{Y} / \mathrm{P}_{1}-\left(\mathrm{W} / \mathrm{P}_{1}\right) \mathrm{L}\left(\mathrm{Y} / \mathrm{P}_{1}\right)$

where $\mathrm{Y} / \mathrm{P}_{1}$ represents the level of output they produce (real GDP in this model), W/ $\mathrm{P}_{1}$ represents real wages and $\mathrm{L}\left(\mathrm{Y} / \mathrm{P}_{1}\right)$ represents the conditional labor demand function evaluated at the production level $\mathrm{Y} / \mathrm{P}_{1}$. I specialize the model further and assume that the conditional labor demand function is given by $\mathrm{L}(\mathrm{y})=(1 / 3) \mathrm{y}^{2}$. It is interesting to notice that, given $\mathrm{Y}$ and $\mathrm{W}$, when the capitalists choose $\mathrm{P}_{1}$ they are automatically determining the level of real GDP, and the level of inflation $\pi_{1}$. A noteworthy feature in this formulation is the ability the capitalists have to also control the real wages in the economy. ${ }^{4}$ Based on the above it is easy to see that, when the capitalists choose $\mathrm{P}_{1}$ they also determine the distribution of income in this economy.

\footnotetext{
${ }^{4}$ This fact distinguishes this model from one in which firms maximize individually and the aggregate arises from the symmetric equilibrium, as an individual firm would not be able to affect real wages through their pricing or output choices.
} 


\section{The 'structuralist' inflation bias}

As usual, we begin studying the model backwards. The first order condition for the maximization problem for the group of capitalists is

$-\mathrm{Y} / \mathrm{P}_{1}{ }^{2}+(1 / 3) \mathrm{WY}^{2} 3 / \mathrm{P}_{1}{ }^{4}=0$

from which it follows that $\mathrm{P}_{1}=(\mathrm{WY})^{1 / 2}$, namely, prices would rise with an increase in nominal wages or an increase in the nominal aggregate demand. The inflation induced by the behavior of capitalists is then equal to

$\pi_{1}=(\mathrm{WY})^{1 / 2}-1$

It is interesting to notice that in this model an increase in $\mathrm{Y}$ raises the price level, the level of real GDP and the total profits for the capitalists. At the same time, an increase in Y depresses real wages and worsens the distribution of income, even though it increases labor demand and the real wage bill.

Given this conduct, the monetary policy authority faces the following dilemma: raising Y leads to a higher real GDP, which is good for everyone (although mostly for the capitalists) but it also leads to a higher $\pi_{1}$ (which depresses real wages). The monetary authority then chooses at Stage 2 a level of Y to maximize

$\mathrm{Y} /\left(1+\pi_{1}\right)-\gamma / 2 \pi_{1}^{2}$

subject to

$$
\pi_{1}=(\mathrm{WY})^{1 / 2}-1
$$


The first order condition for this problem is

$(\mathrm{WY})^{-1 / 2}-\gamma \mathrm{W}+\gamma \mathrm{W}^{1 / 2} \mathrm{Y}^{-1 / 2}=0$

which leads the monetary policy authority to choose a level of nominal aggregate demand given by

$\mathrm{Y}=(1+\gamma \mathrm{W})^{2} /\left(\mathrm{W}^{3} \gamma^{2}\right)$

Combining (5) with (9) we get a level of inflation in equilibrium given by

$\pi_{1}=1 /(\gamma \mathrm{W})$

All this has very interesting implications: At the moment of wage bargaining, labor unions will not take seriously any promise made by the capitalists not to raise prices because it is clear to the unions that the capitalists know that the monetary policy authority, through an increase in $\mathrm{Y}$, will allow them to pass some of the cost increases onto prices "to avoid a recession." In light of this, the labor unions will not accept low nominal wages in Stage 1 and will set the stage for something that is remarkably close to what is known in the literature as a structuralist "cost-push" inflation. ${ }^{5}$ I will call this the structuralist inflation bias that takes place in this model.

All this is easy to see in the model by combining (1) and (10), which leads to a level of inflation in the economy equal to

$$
\pi_{1}=1 /\left[\gamma \mathrm{w}_{0}\left(1+\pi_{0}{ }^{\mathrm{e}}\right)\right]
$$

\footnotetext{
${ }^{5}$ See, e.g., Bernanke (2005) for a brief discussion of the so-called structuralist theories of inflation and Agenor and Montiel (1999) for a much more detailed account.
} 
Hence, if inflation expectations for workers were too low (say, equal to zero), the pricing response of the capitalists given the incentives of the monetary policy authority, would be to produce a positive inflation level, equal to $\pi_{1}=1 /\left(\gamma \mathrm{w}_{0}\right)$, which could not occur in equilibrium. The resulting equilibrium inflation is determined when, in Stage 1, workers set their inflation expectations $\pi_{0}{ }^{\mathrm{e}}$ equal to $\pi_{1}$,

$\pi_{0}{ }^{\mathrm{e}}=\pi_{1}$

which means that the equilibrium inflation level $\pi^{*}{ }_{1}$ is such that $\pi^{*}{ }_{1}\left(1+\pi^{*}{ }_{1}\right)=1 /\left(\gamma \mathrm{w}_{0}\right)$, an inflation level that is far from the "optimal" desired inflation level, as I show below.

\section{Central Bank Independence}

The question, then becomes: can an independent monetary policy authority eliminate the structuralist inflation bias identified above? Following Barro and Gordon (1983 a,b) I now model the monetary policy authority as one that is able to commit to a particular policy, in particular a policy that will not be revised upon knowledge of the inflation expectations of the economic agents. In the context of the model this independence translates into a change in the order in which the events that determine inflation take place.

I assume in this section that the monetary policy authority now commits in Stage 1 to a given level of nominal aggregate demand Y. In Stage 2 unions take Y as given and set their nominal wage demands. Finally, in Stage 3, the capitalists set prices in the economy, taking $\mathrm{Y}$ and $\mathrm{W}$ as given. 
In this economy the capitalists continue to use the rule $\mathrm{P}_{1}=(\mathrm{WY})^{1 / 2}$ for setting prices and unions continue to set nominal wage demands equal to $\mathrm{W}=\mathrm{w}_{0}\left(1+\pi_{0}{ }^{\mathrm{e}}\right)$. What is different is the behavior of the monetary policy authority. Such authority now knows that it does not take inflation expectation as given. In fact, it gets to affect inflation expectations by committing to a given level of Y. As a consequence, the monetary policy authority gets to affect the resulting inflation directly, through nominal demand management, and indirectly, through expectations management.

Therefore, the monetary policy authority views the resulting inflation as the one that comes from combining equations (1), (5) and (12), which produces an inflation level equal to

$\pi_{1}=\mathrm{w}_{0} \mathrm{Y}-1$.

This expression summarizes the effect of aggregate nominal demand on the resulting inflation. Now the monetary policy authority chooses in Stage 1 the level of $\mathrm{Y}$ to maximize

$\mathrm{Y} /\left(1+\pi_{1}\right)-\gamma / 2 \pi_{1}^{2}$

subject to

$\pi_{1}=\mathrm{w}_{0} \mathrm{Y}-1$.

The first order condition for this problem is

$-2 \gamma \mathrm{w}_{0} 2 \mathrm{Y}+2 \gamma \mathrm{w}_{0}=0$

which means that the monetary policy authority chooses a level of Y given by 
$\mathrm{Y}=1 / \mathrm{w}_{0}$,

Combining (15) with (17) allows us to compute the new equilibrium inflation level in the model,

$\pi^{*}=\mathrm{w}_{0} \mathrm{Y}-1=\mathrm{w}_{0}\left(1 / \mathrm{w}_{0}\right)-1=0$,

an inflation level which is exactly zero.

Surprisingly, the independence of the monetary policy authority eliminates the structuralist inflation bias by virtue of committing not to revise its policies upon knowledge of the inflation expectations of the economic agents and the role they play in creating “cost-push” pressures to the price level. This commitment keeps aggregate demand to a level that eliminates all incentive for both the unions and the group of capitalists to push wages or prices upwards. Hence, the structuralist inflation bias completely disappears.

\section{Inflation bias and the distributive struggle}

A possible criticism of the model presented here is that the inflation bias developed above arises simply from the fact that workers have rational expectations and not from any distributive struggle inherent in the model. In this Section I show that this view is incorrect: without the distributive struggle, the inflation bias disappears, even in the presence of rational expectations on the part of the workers and a monetary authority that cannot commit to a particular policy choice. 
To see this consider a model with a timing structure identical to that in Section 2, but where the capitalists do not attempt (or are not able) to depress the real wages that the workers are implicitly requesting. In other words, the capitalists collectively choose at Stage 3 a price level $\mathrm{P}_{1}$ to maximize

$\mathrm{Y} / \mathrm{P}_{1}-\mathrm{w}_{0} \mathrm{~L}\left(\mathrm{Y} / \mathrm{P}_{1}\right)$.

The first order condition for this problem is

$-\mathrm{Y} / \mathrm{P}_{1}^{2}+(1 / 3) \mathrm{w}_{0} \mathrm{Y}^{2} 2 / \mathrm{P}_{1}^{3}=0$,

which leads to an inflation level of

$\pi_{1}=(2 / 3) \mathrm{w}_{0} \mathrm{Y}-1$

It turns out that an economy in which the monetary authority cannot indirectly depress real wages through the capitalist's pricing rules is an economy that the monetary authority has no incentives to inflate.

To see that this happens notice that the monetary authority now chooses at Stage 2 a level of Y to maximize

$\mathrm{Y} /\left(1+\pi_{1}\right)-\gamma / 2 \pi_{1}^{2}$

subject to

$$
\pi_{1}=(2 / 3) \mathrm{w}_{0} \mathrm{Y}-1
$$

The first order condition for this problem is 
$(8 / 9) \mathrm{w}_{0}{ }^{2} \mathrm{Y}-(4 / 3) \mathrm{w}_{0} \gamma=0$,

which leads the monetary policy authority to choose a level of nominal aggregate demand given by

$\mathrm{Y}=3 /\left(2 \mathrm{w}_{0}\right)$

Combining (25) with (21) we get a level of inflation in equilibrium given by

$\pi_{1}=(2 / 3) \mathrm{w}_{0}\left(3 / 2 \mathrm{w}_{0}\right)-1=0$,

that is, an inflation level of zero. Since workers in Stage 1 can anticipate that zero inflation is the inflation that will take place they will request nominal wages equal to $\mathrm{w}_{0}$. In equilibrium, this is also the level of real wages that they will obtain.

Remark. That dynamic inconsistency problems reveal the presence of an underlying conflict of interest is not new: it has been noted previously by Chari, Kehoe and Prescott (1989) and Fischer (1980), among others. ${ }^{6}$ In this paper I simply exploit this fact to build a simple structuralist model of the economy with the purpose of showing that independence of the monetary policy authority would eliminate the inflation bias that the distributive struggle embedded in the dynamic inconsistency problem generates. This is an important thing to do because, as noted in the Introduction, it is believed by many of those who are critical of neoclassical economic models that the independence of the monetary authority is irrelevant for keeping inflation under control when the inflation is generated by distributive struggles between capitalists and workers. 


\section{Further comparison of the three models}

The model without distributive struggle clarifies further the nature of the inflation bias that occurs in the structuralist economy discussed in Section 2. Table 1 shows the equilibrium outcomes for the three models: the model without monetary authority commitment and distributive struggle (model 1 ), the model with monetary authority commitment and distributive struggle (model 2), and the model without monetary authority commitment and no distributive struggle (model 3).

Three facts stand out from the examination of Table 1. First, that the output level in model 3 is higher than that of model 2. Second, that income is equally distributed in model 3, as opposed to models 1 and 2. Third, that inflation, and also real output, are decreasing in $\gamma$.

\begin{tabular}{|c|c|c|c|}
\hline & $\begin{array}{c}\text { No } \\
\text { commitment } \\
+ \\
\text { distributive } \\
\text { struggle }\end{array}$ & $\begin{array}{c}\text { Commitment } \\
+ \\
\text { distributive } \\
\text { struggle }\end{array}$ & $\begin{array}{c}\text { No commitment } \\
+ \\
\text { no distributive } \\
\text { struggle }\end{array}$ \\
\hline Inflation & $\pi_{1}^{*}>0$ & 0 & 0 \\
\hline Real GDP & $1 /\left(\gamma \mathrm{w}_{0}\right)$ & $1 / w_{0}$ & $3 /\left(2 w_{0}\right)$ \\
\hline Real wages & $\mathrm{w}_{0}$ & $\mathrm{w}_{0}$ & $\mathrm{w}_{0}$ \\
\hline $\begin{array}{l}\text { Capitalist's income } \\
\text { share }\end{array}$ & $2 / 3$ & $2 / 3$ & $1 / 2$ \\
\hline Labor's Income share & $1 / 3$ & $1 / 3$ & $1 / 2$ \\
\hline
\end{tabular}

\footnotetext{
${ }^{6}$ See Drazen (2000, ch. 4) for a more elaborate discussion on this.
} 
All these facts, in this structuralist setup, hinge on whether the capitalists, through choice of prices, can affect the level of real wages. If they can't (as in model 2, where the workers are able to adjust their inflation expectations) or won't (as in model 3, where the capitalists accomodate the nominal wages to their own pricing behavior), inflation is zero, as there is no channel through which the monetary authority can affect output.

Such vehicle, in model 1 , is the decline in real wages that is produced by the capitalist's choice of pricing rule. This pricing rule is more aggressive when there is a distributive struggle because, at the margin, part of the real revenue that is lost from raising prices is offset by lower marginal costs of production due to the corresponding decline in real wages that follows from raising prices.

This effect is a distinctive feature of the model presented above, and is absent from the traditional neoclassical or new Keynesian macroeconomic models. In the end all this translates into the capitalists having an incentive to curb production to allow prices to be high, real wages to be low, and to tilt the distribution of income in favor of the capitalist group. In the model without distributive struggle this effect is not present, and a higher real GDP, zero inflation and a more equitable distribution of income arises in consequence.

Finally, as expected, the lower the inflation aversion parameter in model 1, the higher the inflation bias will be, and the higher the observed real output. 


\section{Conclusions}

In this paper I have shown that the ability of the monetary policy authority to commit to a particular set of policies that cannot be affected by the inflation expectations of the economic agents completely eliminates inflation in an economy where all agents are unionized and all owners of firms act as a single monopolist.

To be sure, this model is not intended to be a realistic depiction of any actual economy. The model is extraordinarily simple and atypical. This is deliberate. Its purpose is to serve as a simple albeit extreme benchmark in which to make the point that Central Bank independence can be of tremendous importance even when the economy does not satisfy traditional neoclassical assumptions such as perfect competition and market clearing prices. In fact, this economy is not even New Keynesian in that the distinguishing feature of this model is not the presence of nominal rigidities in an otherwise neoclassical world but instead that wages and prices are direct choices made independently by the union of workers and the cartel of firms to increase their income share.

It was already known (c.f. Clarida, Gali and Gertler, 1999) that New Keynesian economies also exhibit an inflation bias similar to that of Barro and Gordon (1983 a,b). The contribution of this paper has been to show that this inflation bias is also present in very non neoclassical (e.g., structuralist) economies as well.

That this is so reveals that it is the time-inconsistency issue, and not any particular neoclassical or non-neoclassical economic structure, that which generates the inflation bias that Central Bank independence is set to eliminate. This has very important implications for the design of economic policy institutions, as Central Bank independence 
is often viewed as a conservative, neoclassically motivated policy prescription. This point of view no longer seems necessary.

\section{References}

Agénor, Pierre-Richard and Peter J. Montiel, 1999, Development Macroeconomics, $2^{\text {nd }}$ ed., Princeton University Press.

Barro, Robert and David Gordon, 1983a, "Rules, discretion and reputation in a model of monetary policy,” Journal of Monetary Economics, Vol. 12, pp. 101-121.

Barro, Robert and David Gordon, 1983b, "A positive theory of monetary policy in a natural rate model,” Journal of Political Economy, Vol. 91, pp. 589-610.

Bernanke, Ben, 2005, "Inflation in Latin America: A New Era?," Remarks at the Stanford Institute for Economic Policy Research Economic Summit. Available at http://www.bis.org/review/r050216g.pdf.

Chari, Varadarajan; Patrick Kehoe and Edward Prescott, 1989, “Time Consistency and Policy,” in R. Barro, ed., Modern Business Cycle Theory, Harvard university Press.

Clarida, Richard; Jordi Gali and Mark Gertler, 1999, “The Science of Monetary Policy: A New Keynesian Perspective, Journal of Economic Literature, Vol. 37, pp. 1661-1707.

Cukierman, Alex, 1992, Central Bank Strategy, Credibility and Independence: Theory and Evidence, The MIT Press.

Drazen, Allan, 2000, Political Economy in Macroeconomics, Princeton University Press.

Fischer, Stanley, 1980, "Dynamic Inconsistency, Cooperation, and the Benevolent Dissembling Government," Journal of Economic Dynamics and Control, Vol. 2, pp. 93-107. 